\title{
Detection of Methicillin Resistant Staphylococcus aureus in Public Transportation of Kathmandu Valley, Nepal
}

\author{
Khadga Bikram Angbuhang ${ }^{1 *}$, Mukesh Neupane ${ }^{1}$, Aditya Adhikari ${ }^{1}$, Binita KC ${ }^{1}$, Sabina Jha \\ ${ }^{1}$ Department of Microbiology, GoldenGate International College, Kathmandu, Nepal
}
*Corresponding author: Khadga Bikram Angbuhang, Department of Microbiology, GoldenGate International College, Nepal; E-mail: k.subba@goldengate.edu.np

\begin{abstract}
Objectives: The purpose of this study was to assess microbial load and Methicillin Resistant Staphylococcus aureus from surfaces of public transport vehicle.

Methods: The surfaces of public transport vehicle were sampled by swabbing. A total of 56 samples from 28 different vehicles operating in Kathmandu valley were collected and processed according to the standard methodology. The isolates were identified by culture, biochemical tests and subjected to antimicrobial susceptibility testing by modified Kirby-Bauer disk diffusion method following CLSI 2013 guidelines. Methicillin resistant species of Staphylococcus were detected by the virtue of cefoxitin resistance.
\end{abstract}

Results: All 56 samples from the 28 different vehicles were found to have bacterial growth with average bacterial load of $2.47 \pm 1.22 \times 10^{5} \mathrm{CFU} / \mathrm{cm}^{2}$. The gas vehicles were found to be the most contaminated. Out of 56 samples, 35 (25.9\%) were found to be S. aureus growth positive $11(31.4 \%)$ of them being MRSA.

Conclusion: The high flow of people with different health conditions in public transport makes the exchange of microorganism more significant. High bacterial load along with MRSA indicates the threats of transmission of infection among travelers. This is of a great public health concern as the mass population of different health condition is in direct exposure and is prone to get infected.

Key words: Public transport, antibiotic susceptibility testing, MRSA.

\section{INTRODUCTION}

Microbes in public area such as public transport, restaurants, schools, daycare centers can be a critical issue in public health, since they can bring a large number of people together which facilitate the transmission of microbes (Stepanovic et al. 2006; Kassem et al. 2007). This becomes a subject of prime concern when microbes are drug resistant and pathogenic. Therefore, increased attention has been paid to environmental microbes, to the numbers and strains of bacteria found in public places (Reynolds et al. 2005; Kassem et al. 2007; Otter and French, 2009).

The public transportation such as three-wheelers, mini/micro buses, buses, trolleybuses, trams, trains and ferries is mainly available for use by anyone (Scott and Bloomfield, 1990) and generally operates on

Date of Submission: November 18, 2018

Published Online: January 2019 fixed routes. Public transportation system has become increasingly important in urban areas due to mass transit and increased awareness to energy-saving methods of transportation (EPA, 1973; Barrero, 2008). During the travel, various components of the vehicle such as seats, handle, door handle are frequently encountered and may act as the important reservoir for transmission of different pathogenic and non-pathogenic microbes (Oranusi et al. 2016).

Staphylococcus aureus is an opportunistic pathogen often found on the skin, which causes a wide range of infections such as skin lesions, abscesses, endocarditis, septicemia, and toxic shock syndrome. It has now been a pathogen of concern due to the existence of methicillin resistant strains. Also the strains resistant to vancomycin, a drug often referred to as the "drug of Date of Acceptance: December 10, 2018

DOI: https://doi.org/10.3126/tujm.v5i0.22312 
last resort", have been reported (Henriques Normark et al. 2001; Jarraud et al. 2002). Methicillin-resistant Staphylococcus aureus (MRSA) is one of the major human pathogens responsible for mild to severe life threatening infections worldwide (de Lencastre and Tomasz, 2011; ECDPC, 2012). Since the mid-1990s, MRSA has also been identified as the etiological agent of infections acquired in the community (CA-MRSA) (Naimi et al. 2003; Patel, 2009; Graves et al. 2010). Within the last 5 years, MRSA has moved from being primarily a nosocomial pathogen to one that is also found in community areas and public places (Carleton et al. 2004; Popovich et al. 2008).

Microbes in the public transportation can be significant as public health is concerned because of the cases of transfer of organisms either from individual to individual directly or by indirect means which includes transfer from individual to inanimate objects like seats, handles bar etc. and then to other individuals thereby causing infection (Ehrenkranz, 1964; Yeh et al. 2011). This study was performed to screen MRSA from the surfaces of public transport system of Kathmandu, Nepal.

\section{MATERIALS AND METHODS}

In this study, a total of 56 samples from 28 different public vehicles (Handle and seat surface of each vehicle) operating in Kathmandu valley were collected by wet swab methods as described by Yeh et al. (2011) from June to August, 2017. The area of sampling ( $2 \mathrm{~cm} \mathrm{x}$ $4 \mathrm{~cm}$ ) was marked and swabbed with sterile moistened cotton swab and was kept in sterile container having sterile buffered peptone water $(1 \mathrm{ml})$. Similarly, another moistened swabbed was used in the same way and then kept in a dry sterile container simultaneously. Then, it was transported to microbiological laboratory as soon as possible in cold chain condition.
The enumeration of bacteria was performed as described in Isenberg HD (2004). The sample (in buffered peptone water) was serially diluted in sterile normal saline up to $10^{-6}$ and enumerated by spread plate technique incubating overnight at $37^{\circ} \mathrm{C}$. Another swab was cultured on selective and differential media (Mannitol Salt Agar and Blood Agar, HI-media, India), and incubated at $37^{\circ} \mathrm{C}$ for up to 48 hours. The isolated colonies from these media were then identified as 'Staphylococcus aureus' with morphology, Gram staining, and catalase, oxidase, coagulase, DNase tests after subculture on NA.

Modified Kirby-Bauer disk diffusion test based on the guidelines of Clinical and Laboratory Standard Institute (CLSI, 2013) method was used to evaluate the antimicrobial susceptibility pattern of the isolates to a set of antibiotics and determination of methicillin resistance. The antimicrobial agents tested were:

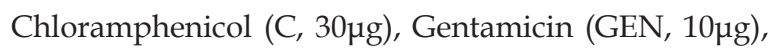
Erythromycin (E, 15 $\mu \mathrm{g})$, Penicillin (PEN, 10 units) and Cefoxitin (CX, 30 $\mu \mathrm{g})$ supplied from Hi-media. Methicillin resistant species of staphylococci were detected by the virtue of cefoxitin resistance on MHA as per CLSI M100-S23 guidelines (CLSI 2013).

\section{RESULTS}

All the 56 surface samples were found to becontaminated with an average bacterial load of $2.47 \pm 1.22 \times 10^{5} \mathrm{CFU} /$ $\mathrm{cm}^{2}$. The samples from the bus were found to be more contaminated $\left(2.57 \pm 0.88 \times 10^{5} \mathrm{CFU} / \mathrm{cm}^{2}\right)$ while that of the tempo were found to be the least contaminated $\left(2.35 \pm 1.84 \times 10^{5} \mathrm{CFU} / \mathrm{cm}^{2}\right)$. The average bacterial load was found to be higher on the seat surfaces $(2.50 \pm 1.51$ $\left.\mathrm{x} 10^{5} \mathrm{CFU} / \mathrm{cm}^{2}\right)$ as compared to the handles $(2.41 \pm 1.93$ $\left.\mathrm{x} 10^{5} \mathrm{CFU} / \mathrm{cm}^{2}\right)$.

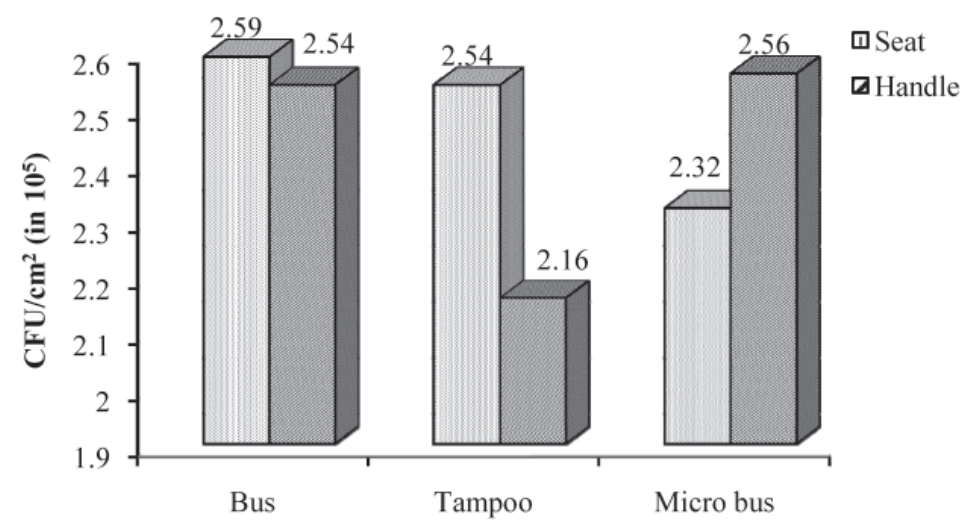

Figure 1: Average bacterial load in vehicles 
The surfaces of the gas vehicles were found to be heavily contaminated $\left(3.14 \pm 1.75 \times 10^{5} \mathrm{CFU} / \mathrm{cm}^{2}\right)$ while that of the electric vehicles were found to be least contaminated $\left(1.48 \pm 0.64 \times 10^{5} \mathrm{CFU} / \mathrm{cm}^{2}\right)$. Sample- wise, the seat of the gas vehicle was found to be heavily contaminated $\left(3.14 \pm 1.75 \times 10^{5} \mathrm{CFU} / \mathrm{cm}^{2}\right)$ while that of the electric vehicle was found to be least contaminated $\left(1.17 \pm 0.79 \times 10^{5} \mathrm{CFU} / \mathrm{cm}^{2}\right)$.

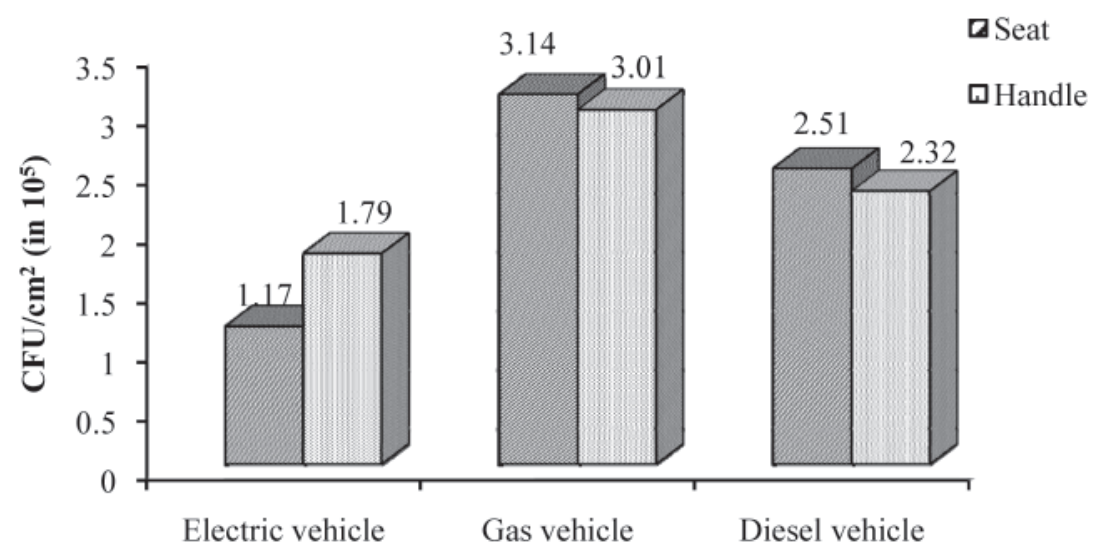

Figure 2: Average bacterial load in the surface of vehicles with respect to fuels

All the vehicles were found to harbor a diverse group of bacteria irrespective of the sample differences. A total of 135 bacteria were isolated from the study with the highest being from the surfaces of the bus 57 (42.2\%). Of them, 35 (25.9\%) were identified to be Staphylococcus aureus and 18 (13.3\%) Coagulase negative staphylococci (CONS).

Table 1: Vehicle wise distribution of the bacterial isolates

\begin{tabular}{|c|c|c|c|c|c|}
\hline S.N. & Vehicle & Number of sample & Bacterial isolates & Number & Percent \\
\hline \multirow[t]{5}{*}{1} & Tampoo & 16 & S. aureus & 11 & 29.7 \\
\hline & & & Gram positive bacilli & 16 & 43.2 \\
\hline & & & CONS & 7 & 18.9 \\
\hline & & & Gram negative bacilli & 3 & 8.1 \\
\hline & Sub total & & & 37 & \\
\hline \multirow[t]{5}{*}{3} & Bus & 24 & S. aureus & 13 & 22.8 \\
\hline & & & Gram positive bacilli & 28 & 49.1 \\
\hline & & & CONS & 8 & 14.0 \\
\hline & & & Gram negative bacilli & 8 & 14.0 \\
\hline & Sub total & & & 57 & \\
\hline \multirow[t]{6}{*}{5} & Micro bus & 16 & S. aureus & 11 & 26.8 \\
\hline & & & Gram positive bacilli & 14 & 34.1 \\
\hline & & & CONS & 3 & 7.3 \\
\hline & & & Gram negative bacilli & 14 & 34.1 \\
\hline & Sub total & & & 41 & \\
\hline & Total & & & 135 & \\
\hline
\end{tabular}

A total of $11(31.4 \%)$ S. aureus were found to be methicillin resistant (MRSA) and 34 (68.5\%) isolates were methicillin susceptible strains (MSSA). Chloramphenicol was found to be the most effective antibiotic in vitro for both MRSA $(11,100 \%)$ and MSSA (34, 100\%). Penicillin was found to be least effective antibiotic in vitro for both MRSA $(11,100 \%)$ and MSSA $(29,85.2 \%)$. 
Table 2: Antimicrobial susceptibility pattern of MSSA and MRSA

\begin{tabular}{llcccc}
\hline \multirow{2}{*}{ S.N. } & \multirow{2}{*}{ Antibiotics } & \multicolumn{2}{c}{ MSSA $(\mathrm{n}=34)$} & \multicolumn{2}{c}{ MRSA $(\mathrm{n}=11)$} \\
\cline { 3 - 6 } & & $\mathrm{S}(\%)$ & $\mathrm{R}(\%)$ & $\mathrm{S}(\%)$ & $\mathrm{R}(\%)$ \\
\hline 1 & Penicillin & $5(14.7)$ & $29(85.2)$ & $0(0)$ & $11(100)$ \\
2 & Erythromycin & $7(20.5)$ & $27(79.4)$ & $3(27.2)$ & $8(72.7)$ \\
3 & Gentamycin & $32(94.1)$ & $2(5.8)$ & $11(100)$ & $0(0)$ \\
4 & Chloramphenicol & $34(100)$ & $0(0)$ & $11(100)$ & $0(0)$ \\
\hline
\end{tabular}

\section{DISCUSSION}

As part of daily activities, many common spaces are shared with other people. This makes it possible to spread diverse microorganisms that can lead to infections. People who use public transport can pass the etiological agents of different infections to other apparently healthy people (Rusin et al. 2002). Due to the regular high flow of mass and the environmental condition of operation, public vehicles have a powerful impact on health of the consumers and the influence is growing globally. Nepal is an under-developed nation and there is no provision of systematic public transport in spite of the mass mobility (UN 2018). Public transport service was started in Kathmandu valley from 1959 and now, different- capacity vehicles such as Tempo, Micro bus, Mini bus, and large bus are in operation in Valley's road and increasing day by day (Pokharel and Acharya, 2015). The public transportation serves people of different health conditions, and become colonized with different pathogenic and non-pathogenic microbes thereby serving as the source of infection to the travelers (Dora et al. 2011). To the best of knowledge, paper regarding the microbiological condition of public transport in Nepal is not available yet. This study was aimed to assess the bacterial load, S. aureus and MRSA in public transport vehicle of Kathmandu Nepal.

All the vehicles were found to be colonized with different microbes with the average bacterial load of $2.47 \pm 1.22 \times 10^{5} \mathrm{CFU} / \mathrm{cm}^{2}$ which indicates poor hygienic condition according to the surface hygiene guideline (BC Centre for Disease Control 2010). The physical contact of the travelling population or their clothing to the surfaces of the bus and the generation of droplets while talking, coughing or sneezing may be primarily responsible for the colonization of the microbes on the solid surface of vehicles (Chowdhury et al. 2016). Similarly, the dust generated in the streets, especially of Kathmandu Valley is also considered to be equally responsible for the microbial colonization (Gautam
2010; Sattar 2016).

The load was in harmony with the reports of Turkey (Tan and Erdoğdu, 2017) but lower than that of Chittagong, Bangladesh 3.1-23.9x10 $\mathrm{CFU} / 4 \mathrm{~cm}^{2}$ (Chowdhury et al. 2016). The variation in the results may be attributed to the geographical diversity and the corresponding socio-economic and anthropogenic status of the population leading to crowding and ill hygienic practices (Chowdhury et al. 2016).

A total of $35(25.9 \%)$ of S. aureus was detected in the study with $31.4 \%$ being methicillin resistant. A number of studies have reported varying degrees of MRSA isolates from the hand-touch surface in the public vehicles worldwide (CS et al. 2018; Iwao et al. 2012; Lutz et al. 2014; Otter and French 2009; Peng et al. 2015). The difference in pattern may be due to the geographical, health status of the living population and socio-economic differences between the sample sites (Bogomolova and Kirtsideli 2009; Jones and Harrison 2004).

Chloramphenicol and Gentamicin were found to be effective against MRSA but the increasing trends of antibiotic resistance among MRSA strains is a matter of concern since the public vehicles can act as a potential point source of infection to the apparently healthy population that may ultimately lead to serious epidemics and potential therapeutic failure (Rusin et al. 2002; Eguia and Chambers 2003; Kramer et al. 2006; Tan and Erdoğdu, 2017). Hence, it is suggestive to consider the proper measures for the sanitation and cleansing of the vehicle that may be primitive detergent washing or recent breath-safe system that may decrease the load of some pathogenic organisms (Lukasik 2009).

\section{CONCLUSION}

The presence of high bacterial load, S. aureus and MRSA on the surfaces of different parts of public vehicles impose the possibility of transmission of serious infection with antibiotics resistant microorganisms. 


\section{ACKNOWLEDGEMENTS}

Authors are most grateful to $\mathrm{CEO}$, principal, $\mathrm{HOD}$ and all the staffs of GoldenGate International College, Kathmandu, Nepal for their facilitation, help and support during the study period.

\section{CONFLICT OF INTEREST}

The authors declare no conflict of interest.

\section{REFERENCES}

Barrero R (2008). Energy savings in public transport. IEEE Veh Tech 3(3): 26-36.

BC Centre for Disease Control (2010). Enviromental hygiene monitoring: a guide for enviromental health officer. Vancouver, BC: BC centre for disease control provicinal health services authority.

Bogomolova E and Kirtsideli I (2009). Airborne fungi in four stations of the St. Petersburg Underground railway system. Int Biodeterior Biodegradation 62: 156-160

Carleton H, Diep B, Charlebois E and Sensabaugh G (2004). Community-adapted methicillin-resistant Staphylococcus aureus (MRSA): population dynamics of an expanding community reservoir of MRSA. J Infect Dis 190(10): 1730-1738.

Chowdhury T, Mahmud A, Barua A, Khalil M, Chowdhury R, Ahamed F and Dhar K ( 2016). Bacterial contamination on hand touch surfaces of public busses in Chittagong City, Bangladesh. J Env Sci Toxic Food Tech 10: 48-55.

CLSI (2013). Performance Standards for Antimicrobial Susceptibility Testing: Twenty third informational supplement. Approved Standard. M100-S23.

CS VK, Prasad S, Patil S, Reddy A, Jha A, KG RK, VL $J$ and KG B (2017). Public transport: a large scale fomite of methicillin-resistant Staphylococcus aureus. Int J Res Med Sci 6(1): 172-176.

de Lencastre H and Tomasz A (2011). The CEM-NET initiative: molecular biology and epidemiology in alliance--tracking antibiotic-resistant staphylococci and pneumococci in hospitals and in the community. Int J Med Microbiol 301(8): 623629.

Dora C, Hosking J and Mudu P (2011). Urban transport and health. In: sustainable transport: A source book for policy-makers in developing cities.
Eschborn, Germany: 1-42.

ECDPC (2012). Antimicrobial resistance surveillance in Europe 2011. Annual Report of the European Antimicrobial Resistance Surveillance Network (EARS-Net). Stockholm.

Eguia JM and Chambers HF (2003). Communityacquired methicillin-resistant Staphylococcus aureus: epidemiology and potential virulence factors. Curr Infect Dis Rep 2003(5): 459-466.

Ehrenkranz N (1964). Person to person transmission of Staphylococcus aureus. Quantitative characterisation of nasal carrer sprading infection. N Engl J Med 271: 225-330.

EPA (1973). Transportation control strategies for the state implementation plan: city of Philadelphia., Research Triangle Park. NC: EPA.

Gautam RD (2010). Air pollution: its causes and consequences with reference to Kathmandu metropolitan city. The Third Pole 8(10): 27-33.

Graves S, Kobayashi S and DeLeo F (2010). Community-associated methicillinresistant methicillinresistant Staphylococcus aureus immune evasion and virulence. J Mol Med 88(2): 109-114..

Henriques Normark B, Novak R, Ortqvist A, Källenius G, Tuomanen E and Normark S (2001). Clinical isolates of Streptococcus pneumoniae that exhibit tolerance of vancomycin. Clin Infect Dis 32(4): $552-558$

Isenberg HD (2004). Clinical Microbiology Procedures Handbook (Vol. 1 and 2). 2nd edition. ASM Press, USA

Iwao Y, Shizuka Y, Takano T, Higuchi W, Nishiyama A and Yamamoto T (2012). Isolation and molecular characterization of methicillin-resistant Staphylococcus aureus from public transport. Microbiol Immunol 56(1): 76-82.

Jarraud S, Mougel C, Thioulouse J, Lina G, Meugnier H, Forey F, Nesme X, Etienne J and Vandenesch F (2002). Relationships between Staphylococcus aureus genetic background, virulence factors, agr groups (alleles), and human disease. Infect Immun 70(2): 631-641.

Jones AM and Harrison RM (2004). The effects of meteorological factors on atmospheric bioaerosol 
concentration- a review. Sci Total Environ 326: 151- 180.

Kassem I, Sigler V and Esseili M (2007). Public computer surfaces are reservoirs for methicillin-resistant staphylococci. ISME J 1(13): 265-268.

Kramer A, Kampf G and Schwebke I (2006). How long do nosocomial pathogens persist on inanimate surfaces? A systematic review. BMC Infectious Diseases 6: 130.

Lewis R (1995). The Rise of Antibiotic-Resistant Infections. FDA Consum 29(7): 11-15.

LukasikG(2009).H1N1 Influenza A Surface Disinfection Testing Report. St. Petersburg, Florida: BCS laboratories, Inc.

Lutz JK, Balen JV, Crawford JM, WilkinsIII JR, Lee J, Nava-Hoet RC and Hoet AE (2014). Methicillinresistant Staphylococcus aureus in public transportation vehicles (buses): Another piece to the epidemiologic puzzle. Am J Infect Control 47: 1285-1290.

Naimi T, LeDell K, Como-Sabetti K and Borchard S (2003). Comparison of community and health careassociated methicillin-resistant Staphylococcus aureus infection. JAMA 290(22): 2976-2984.

Oranusi S, Ebelebe I and Egabadon E (2016). Diversity of commercial Intercity vehicles (Buses and Tricycle). FUTOJNLS 2(1): 235-243.

Otter JA and French GL (2009). Bacterial contamination on touch surfaces in the public transport system and in public areas of a hospital in London. Lett Appl Microbiol 49(6): 803-805.

Patel M (2009). Community-associated meticillinresistant Staphylococcus aureus infections: epidemiology, recognition and management. Drug 69: 693-716.

Peng Y, Ou Q, LinD, Xu P, Li Y, Ye X, Zhou J and Yao Z (2015). Metro system in Guangzhou as a hazardous reservoir of methicillin-resistant Staphylococci: findings from a point-prevalence molecular epidemiologic study. Scientific Report
5: $1-5$

Pokharel Rand Acharya SR (2015). Sustainable transport development in Nepal: challenges, opportunities and strategies. J East Asia Soc Transp Stud 115: 209226.

Popovich K, Weinstein R and Hota B (2008). Are community-associated methicillin-resistant Staphylococcus aureus (MRSA) strains replacing traditional nosocomial MRSA strains? Clin Infect Dis 46(6): 787-794.

Reynolds K, Watt P, Boone S and Gerba C (2005). Occurrence of bacteria and biochemical markers on public surfaces. Int J Environ Health Res 15(3): 225-234.

Rusin P, Maxwell S and Gerba C (2002). Comparative surface-to-hand and fingertip-to-mouth transfer efficiency of gram-positive bacteria, gramnegative bacteria, and phage. J Appl Microbiol 93(4): 585-592.

Sattar SA, Wright, KE, Zargar B, Rubino JR, and Ijaz MK (2016). Airborne infectious agents and other pollutants in automobiles for domestic use: Potential health impacts and approaches to risk mitigation. Journal of Environmental and Public Health Article ID 1548326: 1-12.

Stepanovic S, Cirkovic I, Djukic S, Vukovic D, SvabicVlahovic M (2006). Public transport as a reservoir of methicillin-resistant staphylococci. Lett Appl Microbiol 47(4): 339-341.

Tan AS and Erdogdu G (2017). Microbiological burden of public transport vehicles. Istanbul J Pharm 47(2): 52-56.

UN (2018). https://www.un.org/development/ desa/dpad/wpcontent/uploads/sites / 45/ publication/ ldc_list.pdf. Accesed on 11-11-2018.

Yeh PJ, Simon DM, Millar JA, Alexander HF and Franklin D (2011). A diversity of antibioticresistant Staphylococcus spp. in a public transportation system. Osong Public Health Res Perspect 2(3): 202-209. 